
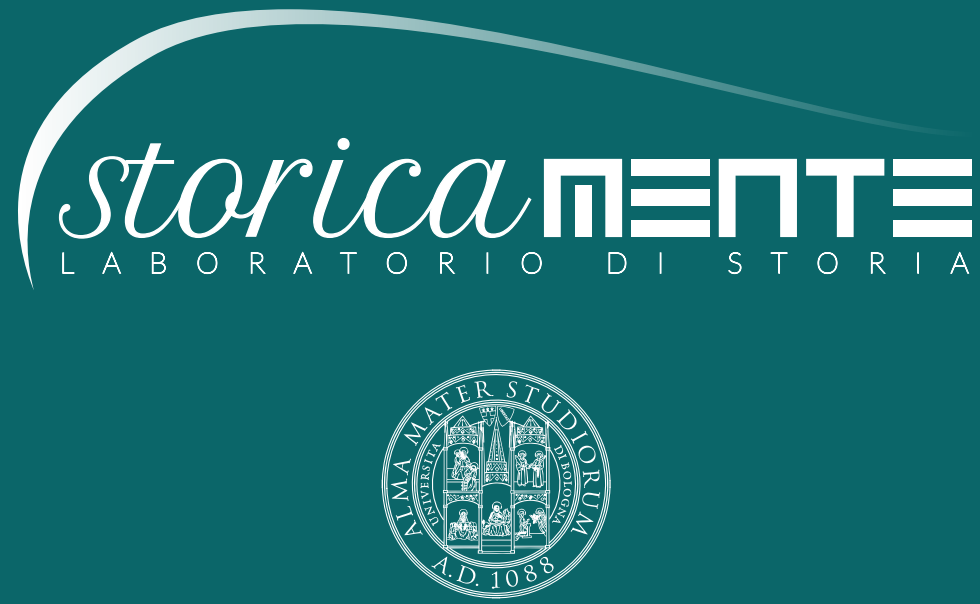

ALMA MATER STUDIORUM

Università di Bologna

Dipartimento di Storia Culture Civiltà

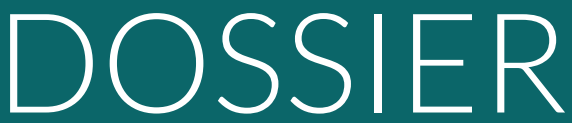

Representations of Fear in History

Empirical / Practical evidence and Methodological Issues 


\section{STORICAMENTE.ORG}

\section{Laboratorio di Storia}

Florian Schleking

Psychedelic Fears. Drug Use as an Emotional Practice in West Germany around 1970

Numero $11-2015$

ISSN: $1825-411 \mathrm{X}$

Art. 24

pp. $1-23$

DOI: $10.12977 /$ stor607

Editore: BraDypUS

Data di pubblicazione: $31 / 12 / 2015$

Licenza: CC BY-NC-ND 4.0 International

Articolo sottoposto a revisione paritaria a doppio cieco

Dossier: Representations of Fear in History: Empirical / Practical evidence and Methodological Issues edited by Vito Gironda, Marica Tolomelli 


\title{
Psychedelic Fears. Drug Use as an Emotional Practice in West Germany around 1970
}

\author{
FLORIAN SCHLEKING \\ Bielefeld University \\ Fakultät für Geschichtswissenschaft, Philosophie und \\ Theologie / Abteilung Geschichte
}

This article studies psychedelic drug consumption in the Federal Republic of Germany in the late 1960s and early 1970s. Using ideas from the History of Emotions and Practice Theory, it offers a fresh look into the making of drug experiences. Doing drugs is analysed as a technology of the self that sought to marshal some feelings while avoiding others. Preparations were as much part of these emotional practices as recognizing and cultivating emotions, or trying to put them into words. The article aims to contribute to the historical study of drugs, emotions and the German counter culture.

\section{Introduction: Drugs and Fear around 1970}

Researching the correlations between so called "psychedelic drugs» and fears after WWII highlights at least three contexts of inquiry: First, on an international level this research emphasizes the roles that LSD and Mescaline played as neuropharmacological weapons in the arms race during the Cold War. Those chemical substances came to be regarded as "truth serums» destined to uncover the enemy's agents, as weapons rendering people unconscious or making them unable to fight and as a means to fundamentally «re-program» human personalities. In the 
eyes of the CIA and the public imagination, the Communist enemy abroad and, later, the countercultural enemy within were already able to deploy similar methods of chemical warfare. Widespread legends such as «acid» poisoning the water supplies and similar stories fostered a collective fear about these mysterious yet potent chemicals [Tanner 2009a; Lee, Shlain 1992].

Fears resulting from public debates about the «drug wave» since the 1960s form a second context of inquiry. This one had far greater consequences on a global level. More and more adolescents consumed more and more hashish, marihuana, LSD and other substances that were successively made illegal. At the very least the impression of a rise in drug use was held and transported by mass media reports, commentaries and studies of social scientists, administration and politics. Consequently, intoxicating substances called «drugs» or "Rauschgifte» in German a peculiar term combining the meanings «intoxication» and "ecstasy» with "poison" - came to be portrayed as a public menace and a social problem which primarily affected and endangered the younger generation. Many news stories told the interested public about drugs' devastating effects on teenage bodies, health and behaviour, as well as on their feelings. A veritable moral panic [Goode, Ben-Yehuda 1994; Garland 2008] arose, which fuelled the diagnosis of the "drug problem» and the "war on drugs" that was declared in the 1970s. The government of the Federal Republic of Germany, like that of many other countries, reacted by enforcing legal measures trying to prohibit drug use? Lastly, parts of the German counter culture around 1970, the student movement(s) of 1968 and the later Alternativmilieu ${ }^{3}$ of the 1970s offered

1 For early sociological studies on the German drug scene, see Herha 1971; Thamm, Schmetz 1973; Gerdes, von Wolffersdorff-Ehlert 1974.

2 Stephens 2007; Briesen 2007; Tanner 2009b; Weinhauer 2006

3 Reichardt 2014; Brown 2013; Reichardt, Siegfried 2010; Klimke, Scharloth 2008a; Siegfried 2008; Gilcher-Holtey 2008. 
a different interpretation of drug use. From their point of view, the so called «mind expanding», "consciousness expanding» or "psychedelic drugs» promised to foster new and supposedly recurring emotional, bodily and psychological experiences [Morris 2014; Shortall 2014]. Furthermore, these sensations and impressions were integrated into methods to better know, realize and transform oneself. In this context, drug use was translated into a medium of subjectification, that is, of governing and producing subjectivities ${ }^{4}$. Doing drugs became one of the practices Michel Foucault called technologies of the self. My paper focuses on those activities and strategies

"which permit individuals to effect by their own means or with the help of others a certain number of operations on their own bodies and souls, thoughts, conduct, and way of being, so as to transform themselves in order to attain a certain state of happiness, purity, wisdom, perfection, or immortality» [Foucault 1988, 18; Foucault 1982].

I therefore limit myself to a comparably small, more localized research field. This, however, enables me to expand the analytic scope in two ways: On the one hand, I do not concentrate exclusively on fear(s) ${ }^{5}$, but rather pose an open question as to which emotions were seen as relevant, necessary, facilitating or hindering in relation to countercultural drug consumption. On the other hand, my paper conceptualizes and analyses emotions, including drug experiences, as emotional practices. The anthropologist Monique Scheer defines emotional practices as «manipulations of body and mind to evoke feelings where there are

\footnotetext{
4 Alkemeyer, Budde, Freist 2013; Reckwitz 2010; Rose 1998

5 In the following, "fear(s)», "anxieties» and synonyms will be used interchangeably and should all be taken as translations of the German words "Angst» (sg.) or «Ängste» (pl.).

6 In this paper the terms «feeling», «emotion», etc. will be used synonymously. From a History of Emotions' perspective, the distinctions between those concepts are blurred at best and should be seen as an object of study, rather than a point of departure. For general overviews of the debates on the History of Emotions see Plamper 2012; Hitzer 2011; Verheyen 2010.
} 
none, to focus diffuse arousals and give them an intelligible shape, or to change or remove emotions already there» [Scheer 2012, 209; Eitler, Scheer 2009]. Following this approach, my essay puts current developments in the History of Emotions to use, which themselves tackle problems raised by feminist scholars about the category of experience in the 1990s [Scott 1991; Shortall 2012]. From this angle, feelings, like experiences, are not entirely individual, private, or apolitical. They should be seen rather as something people learn to experience in a specific way following particular patterns, and as something they mobilize, perform and train with skilful bodies and regulate according to certain rules. In short, emotion is something people try and do. Taking these ideas as points of departure, this article will roughly outline and investigate the emotional practices of psychedelic drug consumption around 1970. In other words, it will regard doing drugs as a type of doing emotion that fabricates emotional subjectivities. Although I will not delve into the societal differences and distinctions of drug consumption - including the intersections of gender, class, age, sexuality, dis/ability, ethnicity, etc. - my essay outlines a couple of heuristic angles that facilitate research into these important questions. For example, dissecting the gendered dimension of drug use would show the male and heteronormative bias of drug discourses [Stephens 2007, 219ff] and reveal that the default consumer was considered to be male. It is an interesting question in need of further investigation, what types of masculinity were created through psychedelic drug use. Highlighting the role of emotions is crucial here [Borutta, Verheyen 2010] - on the one hand, because the production, regulation and display of feelings varies greatly from one social group of men to another; on the other hand, because emotions were such an integral part in the selfdefinition of drug users and their genders.

I will proceed systematically, not chronologically, by breaking down the efforts and actions that drug consumers had to undertake in order to successfully master these practices. I hereby seek to update the 
sociological question Howard S. Becker asked as early as 1953: how does someone become a marihuana user [Becker 1953; 1973; Bancroft 2009]? Becoming an able drug consumer required taking several steps: preparing, identifying and enhancing and, last but not least, communicating and reproducing psychedelic feelings. One after the other, these will be outlined here. In each step, drug consumers were supposed to deal with their fears, e.g. by confronting or ignoring them, minimising or battling them in collective efforts.

\section{Fighting Fears, Making Experiences. Drug Use as an Emotio- nal Practice}

Worries and anxieties occupied a prominent place in public and countercultural portrayals, discussions and implementations of drug consumption. Especially the omnipresent warnings and actions against «bad trips» or "horror trips» - one of the many notions German drug scenes adopted from Anglophone drug idioms - created concerns about the outcomes of doing psychedelic drugs. LSD-«trips» and Hashish-«turns» were constantly depicted as open-ended and therefore risky journeys. Most commentators agreed that psychedelics did offer opportunities for self-exploration and self-realization. But, simultaneously, most remarks underscored the uncertainties and perils of the substances. In the late 1960s, it was commonplace to underline this ambivalence that lay at the heart of doing drugs to expand one's mind and trigger one's feelings. Supporters of psychedelic drugs and several of their adversaries explained unwanted experiences by pointing at the consumer's lack of proficiency and misplaced reactions to surprising drug effects. They more or less disregarded or reduced the intoxicants' properties. Instead, the users - their dispositions and behaviour as well as their social and material environments - were made responsible for the success or failure of lay drug experiments. Consumers could and 
should learn how to influence and control all of these elements and how to navigate feelings during psychedelic intoxication. All they allegedly needed was proper training.

Actualizing one's emotions needed practice and one could never be completely certain if they would really come about at all or in the anticipated ways. First, feeling 'high' did not simply happen when smoking joints or taking acid. These sentiments needed to be triggered, registered, experienced and enjoyed [Becker 1953]. Second, a wide range of psychedelic experiences was promised to be within reach - unfamiliar and possibly life-changing, each one supposedly unique and different from the last one [Steckel 1971; Duhm 1976; Leonhardt 1970]. «All feelings are possible. A person may 'try on' various moods like so many pieces of clothing» [Leary, Metzner, Alpert 1971, 65]. Nonetheless they had to be evoked, studied and cultivated. The focal point and vehicle to navigate feelings was the drug-body and its feelings. Relating to and acting upon corporeal sensations and perceptions were the basic practices of engaging in the psychedelic production of emotions.

\section{Preparing oneself and creating environments - sets and set- tings of drug consumption}

Before even attempting to use drugs for anything, consumers needed to understand and prepare themselves and their immediate contexts along specific parameters. First of all, it was deemed crucial to identify and alter the user's «set». The multifaceted notion of the «set» stemmed from psychology and psychiatry and attributed certain dispositions to the user. The term referred to the consumer's biography and "personality structure», the make-up of his "nervous system» and psychophysical "constitution", his emotional affinity and state of mind, as well as his fears, desires and expectations concerning drugs [Steckel 1971, 
42]. Those traits helped to explain what he or she experienced while being «high». In addition, highlighting the structures of «sets» meant clarifying the features one could use to influence one's sensations. The «set» was deemed to cause particular drug experiences and was therefore utilized as a crucial instrument for self-experiments.

For a promising outcome of the psychedelic «journey», the individual was instructed to undergo rigorous self-examination. This way one could recognize and manage personality traits and moods that would possibly jeopardize drug experiences. "Anxieties, wishes, conflicts, feelings of guilt, hidden passions» were supposed to be risky emotions, but also «distrust» and "cowardice» or "coldness». A wrong management of arising fears was deemed problematic as well [Leary, Metzner, Alpert 1971, 95]. Besides personally acknowledging one's chances and inhibitions, conversations with other users about drug experiences, intimate feelings, doubts and fears regarding the - first or next - «trip» prepared novices on how to conduct the self under the influence of psychedelics.

Reading books and articles, listening to music and studying visual art could also be helpful to understand drug induced impressions. Literature about psychotropic substances and their effects - whether written by journalists, scientists or essayists like Aldous Huxley - as well as publications or ego-documents in which the authors described their experiences contained the information needed. While music and visuals undoubtedly played a preeminent role in shaping the public imagination of psychedelics, specific advice was offered by «handbooks» or other instructive texts which aimed at governing intoxication practices

\footnotetext{
7 A seminal account of the role of set and setting can be found in Zinberg 1984; See also Bancroft: Drugs, 66f.

8 Thamm, Schmetz 1973, 49/50; Herha 1971, 90; Gerdes, von WolffersdorffEhlert, 137.

9 Steckel 1971; Cashman 1967; Haschisch 1969; Olvedi 1972; Masters, Houston 1969; Huxley 2010.
} 
[Olvedi 1972, 197ff; Leary, Metzner, Alpert 1971]. All of these smaller preparations shaped the drug user's "set", moulded his or her knowledge and expectations, This consequently demonstrated and preconfigured what to feel and how to behave when becoming «high».

The "setting" was the second variable to consider when doing drugs ${ }^{10}$. This term described the social and material environments of consumption that were supposed to profoundly affect drug experiences. In the broader sense, "settings» comprised the common spaces young people chose to smoke joints or take other psychedelics, for example apartments, living communities (Wohngemeinschaften), bars, discotheques or concerts". Those types of "settings" point to the fact, that the drug scene of the 1960s and 70s was an urban phenomenon. In its initial phase it was primarily located in large cities like Berlin, Hamburg or Cologne. From there it quickly spread to middle towns and in the early seventies drug consumption reached smaller towns and even rural areas [Weinhauer 2010; Friedrichs 2013].

Creating a «setting» in a narrower sense meant carefully arranging its elements. Finding and manipulating a "setting» implied, on the one hand, picking the «location, aesthetic background, music, lighting [and] the objects» in this environment [Steckel 1971, 42] and, on the other hand choosing the participants. Whether LPs or posters, candles or joss sticks, teas or lollipops [Chotjewitz 1968, 33; Aust 1968, 10; Leary, Metzner, Alpert 1971, 99f] - many stimuli worked together in evoking and navigating between sensory and emotional states of the body. The making of a "setting» was an emotional practice, in which material factors played as significant a role as the human agents themselves. The selection of group members required the same amount of conside-

10 For an interesting perspective on drug «settings» inspired Actor-Network-Theory, see Duff 2007; 2011.

11 Stephens 2007, 56ff, 74ff; Holzer 2007, 365-409; Siegfried 2008, 66-68; Reichardt 2014, 839-850. 
ration. Drug consumers were instructed to control the group's size, its composition and the partakers' relationships. This aimed at excluding unwanted persons from the collective endeavour, eliminating conflicts among the insiders and facilitating collective emotional bonds ${ }^{12}$. It was almost imperative to "feel well in the environment». Thus drug takers found themselves advised - or in fact obliged - to feel «trust» and «compassion» for each other [Steckel 1971, 42; Leary, Metzner, Alpert 1971, 99]. In contrast, «mistrust» or a lack of «empathy» and a shortage of «interpersonal warmth» would jeopardize the drug experiment, because they "made the situation seem threatening» and could bring forth fearful reactions [Leary, Metzner, Alpert 1971, 95]. Hence, everybody had to make an effort to generate positive group feelings and collective emotional relations while at the same time preventing and diminishing negative ones.

At the same time, drug «settings» cannot be regarded as hierarchy-free spaces. On the contrary, ritualized drug consumption frequently went hand in hand with more or less formal positions for the participants: Beginners, novices or apprentices were initiated and escorted by experts, connoisseurs or so called "psychedelic guides» - unanimously translated into the German drug vocabulary as "psychedelische Führer»" ${ }^{3}$. Through past experience and know how, the latter were qualified to train the psychedelic neophytes. Their main tasks included managing their own emotions, observing and recognizing the apprentice's symptoms and directly trying to regulate the novice's behaviour and feelings. 


\section{Identifying and intensifying drug experiences - psychedelic navigation of feeling}

Growing familiarity with drug "trips», and verbal, written or audio-visual depictions of them assembled colourful collections of psychedelic experiences. These accounts constructed and carried knowledge about drug feelings, which made them predictable - at least to a small degree. More importantly, however, they helped the consumers to «immediately recognize symptoms and experiences which might otherwise be terrifying, only due to a lack of understanding as to what was happening. Recognition is the key word» [Leary, Metzner, Alpert 1971, 91]. Indexes of drug symptoms worked as references for observing one's own or, in the case of the "psychedelic guide", other people's feelings while doing drugs. They produced an extensive "phenomenology of psychedelic ecstasy (Phänomenologie des psychedelischen Rausches)» [Steckel 1971, 45] and made consumers identify which of the listed sensations they experienced.

Variations of cognitive, emotional and bodily processes were thoroughly scrutinized. Emotions, moods and responses had to be classified and dealt with. This established a kind of surveillance regime, which directed attention and perception towards or away from «outer objects» and "processes of inner life» [Leary, Metzner, Alpert 1971, 94] and governed sensitivity towards "setting» and «set». Behind this stood the rationale that the drug user could steer his sensory perception and thereby handle his feelings. By controlling their perception, the users could manage their fears and conjure up pleasant, deep or ecstatic emotional states. Of great importance at this point was the "psychedelic guide's» conduct, who could voluntarily or unwillingly stir the "voyager's» worries ${ }^{15}$. Some accounts even went so far as to claim that "almost every negative LSD reaction has been caused by fear on the part of the

\footnotetext{
14 The term «navigation of feeling» was coined by William Reddy 2001.

15 Olvedi 1972, 165, 197; Cashman 1967, 115; Leary 1970, 40; Duhm 1976, 133.
} 
guide which has augmented the transient fear of the subject» [Leary, Metzner, Alpert 1971, 101f]. Apparently, the guide bore a considerable amount of responsibility for the outcome of drug sessions.

In collective drug sessions, veteran drug users ideally not only observed the receptive and susceptible drug users, but also interacted with them and guided them on their "trip». Here they combined verbal and nonverbal practices. By calming them down, reading to them, making them listen to music or showing them pictures, guides should assist the consumers in governing their unsteady psychedelic feelings. Especially when panic or paranoid responses emerged, well-versed experts were called to step in and convey that those reactions were unreal. Or they should find means to distract the apprentice ${ }^{16}$. Additionally, certain body practices offered a way to ease tensions and anxieties and support the user's relief. For instance, this could involve establishing physical contact through hugging, cuddling or holding hands and fostering relaxation through shared breathing techniques [Mein, Wegen 1971, 83; Leary, Metzner, Alpert 1971, 45, 94]. Only in case of an emergency, when a «horror trip» was heralded, a tranquilizer (like Valium) was employed to end the psychedelic experiment [Olvedi 1972, 199]. All in all, interactions between the attendants piloted the drug user's emotions by working on his or her relations to the «setting» and its elements. The subsequent step took this emotional practice - connecting psychedelic subjects to their environments - as a point of departure and expanded upon it.

Among the incentives to take drugs in 1960s Germany, the "intensification of sensory perception» clearly ranked in a top position: drugs reportedly turned "totally mundane things» into "vivid experiences» [Aust 1968, 9f], which were supposed to be enjoyable. A thoughtful arrangement of the "setting» offered the opportunity to adequately «sti-

16 Mein, Wegen 1971, 83; Leary, Metzner, Alpert 1971, 91f; Duhm 1976, 119; Leary 1970, 39f. 
mulate» the senses and thereby work up emotions. If they managed the links between bodies, psychedelics and "settings" properly, drug explorers were sought to augment their senses and sensibilities. In this line of thought and action, drug consumption amplified experiences or opened up novel ones by making them perceptible for the first time [Herha 1971, 28, 159; Steckel 1971, 33; Olvedi 1972, 47].

The «incredible enhancement of sensory consciousness (unglaubliche Verstärkung des sinnlichen Bewußtseins)» [Leary 1970, 22] was constantly praised by drug supporters. It covered all (traditional) senses, from visual and auditory to gustatory, olfactory and tactile sensations. Those sensations often intermingled or activated one another, thereby producing unusual «synesthetic» experiences. Under «synesthetic» circumstances, drug users could see or taste music, feel or listen to colours, etc. In the eyes of psychedelic consumers, generating «intensified» or «synesthetic» experiences improved perceptions and feelings [Steckel 1971, 45-47; Herha 1971, 159]. That is to say, through the concerted usage and stimulation of the drugged body, a psychedelic drug user seemed to move beyond the conventional and limiting patterns of everyday sensory and emotional life [cf. Reckwitz 2010, 479f; Shortall 2014; Feustel 2013, 240ff].

Furthermore, psychedelic drugs promised to alter and augment the relation of users to their emotional selves, but also to each other. Looking for «intensification» or enhancements of sensibility («Sensibilisierung») entailed shaping social relations, cultivating group cohesion and collective emotionality [cf. Bancroft 2009, 64f; Morris 2014]. For better or for worse, drugs were supposed to reveal the "true» feelings of those who took them. They could potentially reinforce relationships between couples or groups and bolster emotional ties. In general, LSD was supposed to "strengthen feelings towards likeable people» but at the same time "increase aversions against unloved partners" [Aust 1968, 11; Mein, Wegen 1971, 84, 87]. Hashish would «facilitate establishing interpersonal contact» and help to "eliminate tensions» between lovers, 
housemates, or larger groups. Smoking cannabis products in the company of others became a mode to bring forward a «feeling of solidarity (Verbundenheit), of non-verbal communication» and foster a deep "mutual understanding ${ }^{» / 7}$. From this point of view, drug consumption opened up a way to intimate emotions and an opportunity to form those very feelings between people.

\section{Telling the tale-communicating and repeating drug experien- ces}

After taking drugs, users frequently talked about their experiences. Reviewing and exchanging personal feelings and insights with trippartners, guides or other acquaintances was a common practice. Communicating what one had felt and feared when experimenting with drugs was advocated as a method to classify and come to terms with the results [Olvedi 1972, 199; Leary, Metzner, Alpert 1971, 105]. Moreover, this offered a chance to compare experiences and interpret them as either characteristic or atypical.

From the beginnings of the "drug wave» onwards, it was commonplace to state that psychedelic emotions, in principle, could not be verbalized completely. Language could only approximately describe those experiences, so that they essentially had to be tried out by everyone who wanted to articulate them [Cashman 1967, 85; Olvedi 1972, 153]. Nevertheless, drug consumers talked about them all the time and much effort went into finding appropriate words. At first glance, this effort may seem paradoxical, but the ineffability of drug experiences turned into one of the main incentives for adolescents to take drugs, to describe their emotional adventures and to use a specific language for this endeavour. Heavily influenced by US-role models, the emerging German drug scene of the 1960s adapted English expressions and integra-

17 Kooymann 1970, 95; Watts 1972, 35, 106f; Mein, Wegen 1971, 100; Vollmar 1977, 139; Wormser 1973, 92; Steckel 1971, 93 
ted them into its own idiom ${ }^{18}$. This created patterns of speech, in which consumers spoke or narrated their own drug experiences. In this sense, both mobilizing and regulating as well as articulating drug feelings were not isolated and untouched by society but quite the contrary: all of these activities were essentially and distinctly social practices. After all, the psychedelic doing of emotion depended on dissemination and repetition. Drug use spread through a combination of channels, including direct demonstration and tutelage, the more or less unintentional display and imitation by way of trial. These rehearsals came to be known as "turning on» oneself and others, translated into German as «antörnen» [Leary 1970; Herha 1971, 194; Wormser 1973, 350]. Amongst other things, «antörnen» meant promoting, teaching and learning how to consume the substances - that is, for example, how to smoke a «joint» [Kontrollieren: «Tibet» 1969, 90; Herha 1971, 17] - and how to construct a «setting», leading back to the first steps in doing drugs. "The nature of the experience depends almost entirely on set and setting» [Leary, Metzner, Alpert 1971,13] - and both could be rearranged over and over again to produce new kinds of feelings. The claim that each and every drug experiment was unique functioned as an additional impetus, because any session was said to produce «an abundance of new impressions, experiences and insights» [Steckel 1971, 41, 45, 34].

Despite all that, drug sessions could go wrong if the praised, expected and desired emotions simply did not arise or if recorded fears culminated into "horror trips» [Leonhardt 1970, 43; Olvedi 1972, 25; Steckel 1971, 48-51, 78-80]. Chances and risks of doing drugs as an emotional practice persisted - and motivated the users to try anew and vary «set», «setting» and activities before and while becoming intoxicated. In this respect, psychedelic drug consumption came full circle and was not

18 Reavis 1967, 251-256; Forschungsgruppe S der Freien Universität Berlin 1971; «Bambinos» 1971; Leonhardt 1970, 353-375; Lösch et. al.: 1971, 73-88; Wormser 1973, 94-104 
just repeatable, but also in need of repetition. And this iterative drive strengthened the attachment to "mind expanding» substances and the fabrication of feelings with them - and therefore stabilized drug-mediated emotional subjectivity.

\section{Conclusion: Doing Drugs and the History of Emotions}

In the late sixties and early seventies, doing psychedelic drugs was seen as a partially predictable, but nonetheless risky activity that relied on the consumer's precautions and operations. This conviction became the starting point for experimenting with drugs to achieve certain extraordinary emotional states, a goal that found its followers among adolescents in many subcultural contexts. By focusing on drug use as a practice of subjectification, I was have shown that during the 1960s a specific kind of emotional subjectivity emerged in the West German counter culture.

I used a case study on Western Germany around 1970 to bring a new perspective to the historical investigation of drug use. Even though drugs were discussed as possible threats in the context of the Cold War and the «drug problem» targeting adolescents, I looked at drug use from a different angle, exploring drug consumption as an emotional technology of the self, which was governed by specific rule and practices. I asked what users were advised to do to administer their feelings and focussed, in particular, on a series of micro-practices that gradually shaped the user's subjectivity.

One of the main incentives for the users to try and control their feelings before and during their drug experiences was their fear of the ominous «horror trip». First, to avoid these negative effects, potential users were urged to prepare themselves properly by entering the right «set» and an uplifting "setting». In these arrangements, personal, media, material and social factors needed to be taken into account, since all of 
them affected the experience. In a second step, they had to learn how to identify and use the enhanced and amplified repertoire of feelings that could be experienced during a trip. The help of the group and psychedelic guides in particular were crucial to prevent a user from entering the realm of the horror trip. Again, internal and external factors were combined to reach a satisfying outcome. In the third step, the new feelings were verbalised using a new vocabulary. At the same time, the general consensus was that words could never fully describe what happened during a trip. Only continually and repeatedly doing drugs would lead the user to a whole new level of existence. So people tried again and again, ever optimising their own performances and then again talking about it and comparing it with others.

From an analytical standpoint this article addresses essential questions for the history of fear(s) in particular and the History of Emotions in general ${ }^{1}$. The first passage on "sets» and "settings» shows that knowledge and environments play a substantial part in framing, generating and expressing emotions. Therefore, attempts to historicize emotions need to search for discourses - including scientific, therapeutic or religious one $^{20}$ - on what a person could feel in doing something and the spaces and places, where those experiences could be made [Reckwitz 2012]. How did expectations and requests to feel something prefigure what people actually felt while engaging in social practices? Which spaces encouraged a specific emotional expression, which required, enforced or restricted certain emotions and which rules regulated those situations - whether in the court or the living room, at political demonstrations or in the sports arena, in a church or in a bunker?

The second part hints at norms and collective attempts to control and navigate bodily states of emotion. To what extend were people able to actualize the emotions they were willing or obliged to have or invoke

\footnotetext{
19 Cf. Plamper 2012; Hitzer 2011; Verheyen 2010; Plamper 2010

20 Cf. Biess, Gross (eds.) 2014; Tändler, Jensen 2012; Maasen et. al. 2011.
} 
in others? Which ways proved (un)successful in furthering a feeling of togetherness, of belonging to a specific group and which methods were used to strengthen the boundaries of that group? To use another example, which emotional activities enforced solidarity of militant organizations and fuelled hate against their supposed enemies? Moreover, in a broader sense, these remarks invite researchers to look more closely at the links between personal and collective feelings and their possible mutual reinforcements or divergences.

My last step points to the general problem of speaking about emotions and the difficulty of translating feelings into words. This, however, should not be considered an impassable barrier by historians that prevents them from inquiring into the history of emotions. Historians should not put this off as an unsurmountable empirical impasse of the source material which brings their inquiries to a halt. In my opinion, this obstacle should become a starting point for asking questions. As my research into the drug scene shows, it was a persistent and well-known difficulty for historical actors to put their feelings into words. How did people in a certain period and context communicate their sentiments? Which concepts, figures of speech, narratives, arguments, representations, or languages did they use to express themselves? [Scheer 2012; cf. Frevert et. al. 2011].

Additionally, the problem of articulating emotions did not necessarily hinder communication, but could also facilitate it. This communicative function is crucial to acknowledge. Psychedelic drug users reflected upon their struggle to speak and considered it a problem - just as today's historians do. Yet, they were actually propelled forward by this conundrum. The impulse to communicate emotions was as much part of their emotional practices as labelling them. In psychedelic technologies of the self, doings and sayings were intricately intertwined - and emotions were not only «represented», but «done» and «fabricated» in words and deeds. Explorations into the History of Fear(s) as well as broader studies on political, social and cultural history could certainly 
benefit from confronting and answering the kind of research questions, this investigation of emotional practices brought up.

\section{References}

\section{Primary Sources}

Aust S. 1967, LSD in Deutschland, «Konkret», 12, 16-21.

- 1968, Liebe unter LSD, «Konkret», 1, 8-12.

Cashman J. 1967, LSD. Die «Wunderdroge», Frankfurt a.M./Berlin: Ullstein.

Chotjewitz P. O. 1968, Haschisch!, «Konkret», 5, 32-36.

Duhm D. 1976, Der Mensch ist anders. Besinnung auf verspottete, aber notwendige Inhalte einer ganzheitlichen Theorie der Befreiung. Kritik am Marxismus. Beiträge zur Korrektur, Lampertheim: Köhler (I ed. 1975).

Forschungsgruppe S der Freien Universität Berlin 1971, Drogenglossar. Ausdrücke und Begriffe der Berliner Drogenszene, Berlin.

Gerdes K., von Wolffersdorff-Ehlert C. 1974, Drogenscene: Suche nach Gegenwart. Ergebnisse teilnehmender Beobachtung in der jugendlichen Drogensubkultur, Stuttgart: Enke.

Haschisch - Tibet ist überall 1969, «Der Spiegel», 46, Nov. 10, 76-102.

Herha J. 1971, Erfahrungen mit Haschisch. Ergebnisse einer Befragung von 234 Konsumenten von Cannabis und anderen Drogen in Berlin (West) 1969/70, Freie Universität Berlin 1971.

Huxley, A. 2010 (1970), Die Pforten der Wahrnehmung. Himmel und Hölle. Erfahrungen mit Drogen, München: Piper.

Kooymann M. 1970, Medizinische Aspekte des Drogen-Konsums, in Neumann N. (ed.) 1970, Hasch und andere Trips. Fakten, Informationen, Analysen, Hamburg: konkret, 78-113.

Krassner P. 1967, Ein unhöfliches Interview mit Timothy Leary, in Edward Reavis (ed.) 1967: Rauschgiftesser erzählen, Frankfurt: Bärmeier \& Nikel, 281-305.

Leary T. 1970, Politik der Ekstase, Hamburg: Christian Wegner.

Leary T., Metzner R., Alpert, R. 1971, Psychedelische Erfahrungen. Ein Handbuch nach Weisungen des Tibetanischen Totenbuchs, Weilheim: Otto Wilhelm Barth.

Leonhardt R. W. 1970, Haschisch-Report. Dokumente und Fakten zur Beurteilung eines sogenannten Rauschgifts, München: Piper.

Masters, R. E. L., Houston J. 1969, Psychedelische Kunst, München/Zürich: Droemer 
Knaur.

Mein W., Wegen L. 1971, Die Pop-Kommune. Dokumentation über Theorie und Praxis des Zusammenlebens, München: Heyne.

Olvedi U. 1972, LSD-Report, Frankfurt a.M.: Suhrkamp.

Reavis E. (ed.) 1967, Rauschgiftesser erzählen, Frankfurt a.M.: Bärmeier \& Nikel.

Steckel R. 1971, Bewusstseinserweiternde Drogen. Eine Aufforderung zur Diskussion, Berlin: Voltaire (I. ed. 1969).

Thamm B. G., Schmetz W. 1973, Drogenkonsumenten im Untergrund. Drogengefährdete und -abhängige Jugendliche in ihren subkulturellen Umfeldern der Drogenszene im Untergrund West-Berlins, Berlin.

Watts A. W. 1972, Kosmologie der Freude. Mit einem Vorwort von Timothy Leary und Richard Alpert, Darmstadt: März.

Wormser R. 1973 (ed.), Drogen. Erfahrung und Erkenntnis. Selbstzengnisse, Dokumente, Analysen, Berlin: Luchterhand.

\section{Literature}

Alkemeyer T., Budde, G., Freist D. (eds.) 2013, Selbst-Bildungen. Soziale und kulturelle Praktiken der Subjektivierung, Berlin: de Gruyter.

Bancroft A. 2009, Drugs, Intoxication and Society, Cambridge: Polity.

Becker H. S. 1953, Becoming a Marihuana User, "The American Journal of Sociology», 59 (3): 235-242.

Becker H. S. 1973, Außenseiter. Zur Soziologie abweichenden Verhaltens, Frankfurt a.M.: Fischer

Biess F. 2008, Die Sensibilisierung des Subjekts. Angst und «Neue Subjektivität» in den 1970er Jahren, «WerkstattGeschichte», 17 (49): 51-71.

Biess F., Gross D. M. (eds.) 2014, Science and Emotions after 1945. A Transatlantic Perspective, Chicago: University of Chicago Press.

Borutta M., Verheyen N. (eds.) 2010, Die Präsenz der Gefühle. Männlichkeit und Emotion in der Moderne, Bielefeld: transcript.

Briesen D. 2005, Drogenkonsum und Drogenpolitik in Deutschland und den USA. Ein historischer Vergleich, Frankfurt a.M.-New York: Campus.

Briesen D. 2007, Die Drogenwelle in der Bundesrepublik Deutschland in den frühen 70er Jahren. Beispiele, Verallgemeinerungen und ein Blick auf die Post-68er Generation, in Briesen D., Weinhauer K. (eds.) 2007, Jugend, Delinquenz und gesellschaftlicher Wandel. Bundesrepublik Deutschland und USA nach dem Zweiten Weltkrieg, Essen: Klartext, 43-69.

Brown T. S. 2013, West Germany and the global sixties. The Antiauthoritarian Revolt, 1962-1978, Cambridge: Cambridge Univ. Press. 
Duff C. 2007, Towards a theory of drug use contexts. Space, embodiment and practice, "Addiction Research \& Theory», 15 (5): 503-519.

Duff C. 2011, Reassembling (social) contexts. New directions for a sociology of drugs, "International Journal of Drug Policy», 22 (6): 404-406.

Dyck E. 2008, Psychedelic psychiatry. LSD from clinic to campus, Baltimore: Johns Hopkins Univ. Press.

Eitler P., Scheer M. 2009, Emotionengeschichte als Körpergeschichte, "Geschichte und Gesellschaft», 35 (2): 282-313.

Feustel R. 2013, Grenzgänge. Kulturen des Rauschs seit der Renaissance, Paderborn: Wilhem Fink.

Foucault M. 1994, Das Subjekt und die Macht, in Dreyfus H. L., Rabinow P. (eds.) 1994: Michel Foucault - jenseits von Strukturalismus und Hermeneutik, Weinheim: Beltz Athenäum, 242-261.

- 2005, Technologien des Selbst, in Defert D., Ewald F., Bischoff M. (eds.), Schriften in vier Bänden, Frankfurt a.M.: Suhrkamp, 966-999.

Frevert U. et. al. 2011, Gefühlswissen. Eine lexikalische Spurensuche in der Moderne, Frankfurt a.M.: Campus.

Friedrichs J.-H. 2013, Urban Spaces of Deviance and Rebellion. Youth, Squatted Houses and the Heroin Scene in West Germany and Switzerland in the 1970s and 1980s, University of British Columbia.

Gammerl, B. (ed.) 2012, Emotional styles. Concepts and Challenges, "Rethinking history», 16 (2): 161-175.

Gilcher-Holtey I. 2001, Die 68er Bewegung. Deutschland - Westeuropa - USA, München: Beck.

Gilcher-Holtey I. (ed.) 2008, 1968. Vom Ereignis zum Mythos, Frankfurt a.M. Suhrkamp.

Häberlen J. C., Smith J. P. 2014, Struggling for Feelings. The Politics of Emotions in the Radical New Left in West Germany, c. 1968-84, "Contemporary European History", 23 (4): 615-637.

Hitzer B. 2011, Emotionsgeschichte - ein Anfang mit Folgen. Forschungsbericht, "H-Sozu-Kult http://hsozkult.geschichte.hu-berlin.de/forum/2011-11-001.pdf».

Holzer T. 2007, Die Geburt der Drogenpolitik aus dem Geist der Rassenhygiene. Deutsche Drogenpolitik von 1933 bis 1972, Norderstedt-Mannhein: Books on Demand.

Klimke M., Scharloth J. (eds.) 2008a, 1968. Handbuch zur Kultur- und Mediengeschichte der Studentenbewegung, Bonn: Bundeszentrale für politische Bildung

- (eds.) 2008b, 1968 in Europe. A History of Protest and Activism, 1965-1977, Basingstoke-New York: Palgrave Macmillan.

Knoch H. (ed.) 2007, Bürgersinn mit Weltgefühl. Politische Moral und solidarischer Protest 
in den sechziger und siebziger Jahren, Göttingen: Wallstein.

Lee M. A., Shlain B. 1992, Acid dreams. The complete social history of LSD: The CIA, the Sixties, and beyond, New York: Grove Press.

Maasen S. et. al. (eds.) 2011, Das beratene Selbst: Zur Genealogie der Therapeutisierung in den "langen» Siebzigern, Bielefeld: transcript.

Morris W. 2014, Spiel Appeal: Play, Drug Use and the Culture of 1968 in West Germany, "Journal of Contemporary History», 49 (4): 770-793.

Moser J. 2013, Psychotropen. Eine LSD-Biographie, Konstanz: Konstanz University Press.

Plamper J. 2010, The History of Emotions: An Interview with William Reddy, Barbara Rosenwein, and Peter Stearns, "History and Theory", 49 (2): 237-265.

- 2010, Geschichte und Gefühl. Grundlagen der Emotionsgeschichte, München: Siedler.

Reckwitz A. 2010 (2006), Das hybride Subjekt. Eine Theorie der Subjektkulturen von der bürgerlichen Moderne zur Postmoderne, Weilerswist: Velbrück.

-2012, Affective spaces: A praxeological outlook, in Gammerl, B. 2012 (ed.), Emotional Styles. Concepts and Challenges, "Rethinking history», 16 (2), 241-258.

Reddy W. 2001, The Navigation of Feeling. A Framework for the History of Emotions, Cambridge: Cambridge University Press.

Reichardt S. 2005, «Wärme» als Modus sozialen Verhaltens? Vorüberlegungen zu einer Kulturgeschichte des linksalternativen Milieus vom Ende der sechziger bis Anfang der achtziger Jahre, "vorgänge», 44 (171/172): 175-187.

- 2014, Authentizität und Gemeinschaft. Linksalternatives Leben in den siebziger und frühen achtziger Jahren, Berlin: Suhrkamp.

-, Siegfried D. (eds.) 2010, Das Alternative Milieu. Antibürgerlicher Lebensstil und linke Politik in der Bundesrepublik Deutschland und Europa 1968-1983, Göttingen: Wallstein.

Rose N. 1998, Inventing our selves. Psychology, power and personhood, Cambridge: Cambridge University Press.

Scharloth J. 2011, 1968. Eine Kommunikationsgeschichte, München: Fink.

Scheer, Monique 2012, Are Emotions a Kind of Practice (And Is That What Makes Them Have a History)? A Bourdieuian Approach to Understanding Emotion, "History and Theory", 51 (2): 193-220.

Schildt A., Siegfried D. (eds.) 2006, Between Marx and Coca-Cola. Youth cultures in changing European societies 1960-1980, New York-Oxford: Berghahn.

- 2009, Deutsche Kulturgeschichte. Die Bundesrepublik - 1945 bis zur Gegenwart, Bonn: Bundeszentrale für politische Bildung 2009.

Shortall S. 2014, Psychedelic Drugs and the Problem of Experience, in Withington, P., 
McShane A. (eds.) 2014, Cultures of intoxication, "Past \& Present», Supplement 9, Oxford: Oxford University Press, 187-206.

Siegfried D. 2006, Time is on my side. Konsum und Politik in der westdeutschen Jugendkultur der 60er Jahre, Göttingen: Wallstein.

- 2008, Sound der Revolte. Studien zur Kulturrevolution um 1968, Weinheim-München: Juventa.

Stephens R. P. 2007, Germans on drugs. The complications of modernization in Hamburg, Ann Arbor: University of Michigan Press.

Tändler M., Jensen U. (eds.) 2012: Das Selbst zwischen Anpassung und Befreiung, Psychowissen und Politik im 20. Jahrhundert, Göttingen: Wallstein.

Tanner J. 1999: Cannabis und Opium, in Hengartner T., Merki C. M. (eds.) 1999, Genußmittel. Ein kulturgeschichtliches Handbuch, Frankfurt-New York: Campus, 195-227.

- 2008, "The Times They Are A-Changing». Zur subkulturellen Dynamik der 68erBewegungen, in Gilcher-Holtey I. (ed.), 1968. Vom Ereignis zum Mythos, Frankfurt a.M.: Suhrkamp, 275-295.

- 2009, "Doors of perception" versus «Mind control». Experimente mit Drogen zwischen kaltem Krieg und 1968, in Griesecke B. et. al. (eds.) 2009, Kulturgeschichte des Menschenversuchs im 20. Jahrhundert, Frankfurt a.M.: Suhrkamp, 340-372.

- 2009, Kurze Geschichte und Kritik der Drogenprohibition im 20. Jahrhundert, "zeitenblicke», 8, no. 3. http://www.zeitenblicke.de/2009/3/tanner/index_html.

Verheyen V. 2010, Geschichte der Gefühle, Version: 1.0 «Docupedia-Zeitgeschichte», (http://docupedia.de/zg/Geschichte_der_Gef.C3.BChle?oldid=97404).

- 2008, Diskussionsfieber. Diskutieren als kommunikative Praxis in der westdeutschen Studentenbewegung, in Klimke M., Scharloth J. (eds.) 2008, 1968. Handbuch zur Kulturund Mediengeschichte der Studentenbewegung, Bonn: Bundeszentrale für politische Bildung, 209-221.

Weinhauer K. 2006, Drug Consumption in London and Western Berlin during the 1960s and 1970s. Local and Transnational Perspectives, "Social History of Alcohol and Drugs», 21 (2): 187-224.

- 2006, The End of Certainties. Drug Consumption and Youth Delinquency in West Germany, in Schildt A., Siegfried D. (eds.) 2006, Between Marx and Coca-Cola. Youth cultures in changing European societies 1960-1980, New York-Oxford: Berghahn, 376-397.

- 2010, Heroinszenen in der Bundesrepublik Deutschland und in Großbritannien der Siebziger Jahre, in Reichardt S., Siegfried D. (eds.) 2010, Das Alternative Milieu. Antibürgerlicher Lebensstil und linke Politik in der Bundesrepublik Deutschland und Europa 1968-1983, Göttingen: Wallstein, 244-264.

Withington, P., McShane A. (eds.) 2014, Cultures of intoxication, «Past \& Present», 
Supplement 9, Oxford: Oxford University Press.

Zinberg, N. E. 1984, Drug, set, and setting. The basis for controlled intoxicant use, New Haven: Yale University Press. 